\title{
Upgrading of TGA/DTA analyzer Derivatograph
}

Rudolf PODOBA - Department of Physics, Constantine the Philosopher Univeristy and Department of Physics, Faculty of Civil Engineering, Slovak University of Technology - rudolf.podoba@ukf.sk - rudolf.podoba@stuba.sk

Anton TRNíK - Department of Physics, Constantine the Philosopher Univeristy and Department of Materials Engineering and Chemistry, Czech Technical University - atrnik@ukf.sk LuBoš PODOBNíK - Department of Physics, Constantine the Philosopher University - lubos.podobnik@ukf.sk

Received: 23. 11. 2011. " Érkezett: 2011. 11. 23. http://dx.doi.org/10.14382/epitoanyag-jsbcm.2012.5

An upgraded version of the TGA/DTA analyzer Derivatograph $1100^{\circ}$ is described. A linear variable differential transformer (LVDT) is used as a sensor of the balance movement to register changes in the sample mass. The furnace temperature measured by a Pt-PtRh10 thermocouple located in its original position is controlled using the temperature programmer TLK 38. Thermocouples for DTA and their connections are left in the original state. Electrical signals from LVDT and thermocouples are sent to multimeter AGILENT 34972A which is connected to a PC. The program records the time of the measurement, furnace temperature, difference between the temperatures of the measured and the reference samples, and mass of the sample. The program's output is a graph with continuous TGA and DTA curves.

Keywords: differential thermal analysis (DTA), thermogravimetric analysis (TGA)
Mgr. Rudolf PODOBA

(1984) Education: Constantine the Philosopher University in Nitra, physics of materials (degree - Mgr., 2009). Constantine the Philosopher University in Nitra, physics of materials (PhD. Student, 2009). Field of research: thermal analyses of the green clay ceramic materials.

RNDr. Mgr. Anton TRNík, PhD (1978) Education: Constantine the Philosopher University in Nitra, Physics and Computer science (degree Mgr. 2003); PhD study of Physics of materials at Constantine the Philosopher University in Nitra (degree PhD. 2006). Field of research: mechanical properties and thermophysical properties of building ceramics, measurement science.

Mgr. Ĺuboš PODOBNík (1986) Education: Constantine the Philosopher University in Nitra, mathematics and physics (degree - Bc., 2008). Charles University in Prague, mathematics and physics (degree - Mgr., 2011). Constantine the Philosopher University in Nitra, physics of materials (PhD. Student, 2011). Field of research: the phase changes in silicate ceramics.

\section{Introduction}

The thermal analyses DTA and TGA are widely used in research of building materials, particularly in the development of building ceramics. Results are easier to interpret if both DTA and TGA are conducted during the same experiment using a combined analyzer. That is possible in the DTA/TGA analyzer Derivatograph $1100^{\circ}$, system F. Paulik, J. Paulik and L. Erdey [1]. Although the present-day DTA/TGA analyzers work well for small powder samples with mass less than $50 \mathrm{mg}$, in some cases it is preferable to measure compact samples of sizes and masses comparable to samples used in thermodilatometry or thermomechanical analyses. A derivatograph can measure compact samples up to $5 \mathrm{~g}$ and register a mass change up to $\pm 1 \mathrm{~g}$. This ability makes its modernization an important topic to study.

The original Derivatograph measured thermo-emf from thermocouples by mirror galvanometers which transform the electrical voltage into a motion of a light beam. The movement of laboratory balance was also monitored by a light beam. Four light beams (temperature, DTA, TGA and DTG) drew lines on a photographic paper. The temperature programmer was electromechanical.

The objective of this study is to describe an upgrade the original Derivatograph.

\section{Short description of the modernized Derivatogrpah}

A linear variable differential transformer (LVDT) was used as a sensor of balance movement to register change of the sample mass, see Fig. 1. The LVDT INPOS (ZPA Jinonice, Czech Republic), is very suitable for this purpose because its core can be easily detached from the body of the LVDT, and the core can be moved in the LVDT opening without a mechanical contact if the opening is in the vertical position. The LVDT was calibrated directly in the analyzer by known weights which were put on an empty crucible. The relationship between the output voltage from the LVDT and the mass of the sample is linear; its sensitivity is reported in Table 1 .
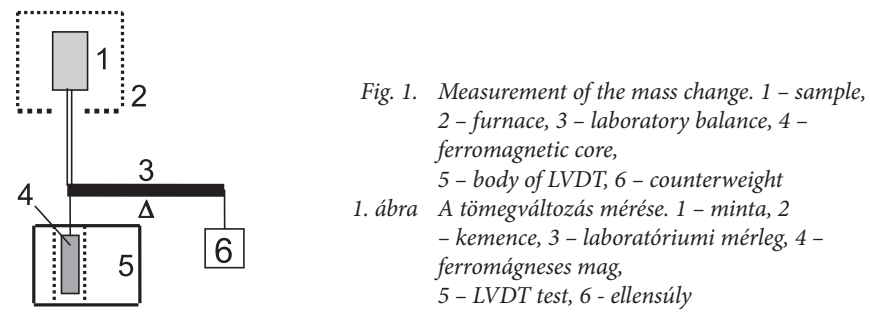

Fig. 1. Measurement of the mass change. 1 -sample, 2 - furnace, 3 - laboratory balance, 4 ferromagnetic core 5 - body of LVDT, 6 - counterweight

1. ábra A tömegváltozás mérése. 1 - minta, 2 - kemence, 3 - laboratóriumi mérleg, 4 ferromágneses mag, 5 - LVDT test, 6 - ellensúly

\begin{tabular}{c|c|c|c|c|c|c}
$\begin{array}{c}\text { sensitivity } \\
\text { of balance }\end{array}$ & $20 \mathrm{mg}$ & $50 \mathrm{mg}$ & $100 \mathrm{mg}$ & $200 \mathrm{mg}$ & $500 \mathrm{mg}$ & $1000 \mathrm{mg}$ \\
\hline $\begin{array}{c}\text { sensitivity } \\
\text { of LVDT }\end{array}$ & 15.825 & 8.486 & 4.692 & 2.443 & 1.059 & 0.534
\end{tabular}

Table 1. Sensitivity of LVDT [mV/mg] for different sensitivities of balance 1. táblázat Az LVDT érzékenysége [ $\mathrm{mV} / \mathrm{mg}]$ a mérleg különbözö érzékenységei mellett

The furnace temperature measured by a Pt-PtRh10 thermocouple located in its original position is controlled using a temperature programmer TLK 38 connected to the power block. We used a solid state relay in the power block instead of the original electromechanical relay. The rest of the power block is left without changes.

The thermocouples for DTA and their connections are left in their original positions.

The derivative thermogravimetry (DTG) can be also performed by the Derivatograph $1100^{\circ}$. The induced electrical voltage which comes from a very slow movement of the coil in a gap of the permanent magnet is very low and, in our conditions, it contains a significant amount of noise. The noise is probably caused by the vibrations of the laboratory balance. The noise is also recorded by the LVDT, so the TGA line is not ideally smooth. The numerical derivative of the data gives the DTG line with a big noise. Those are the reasons why we did not use the DTG. 


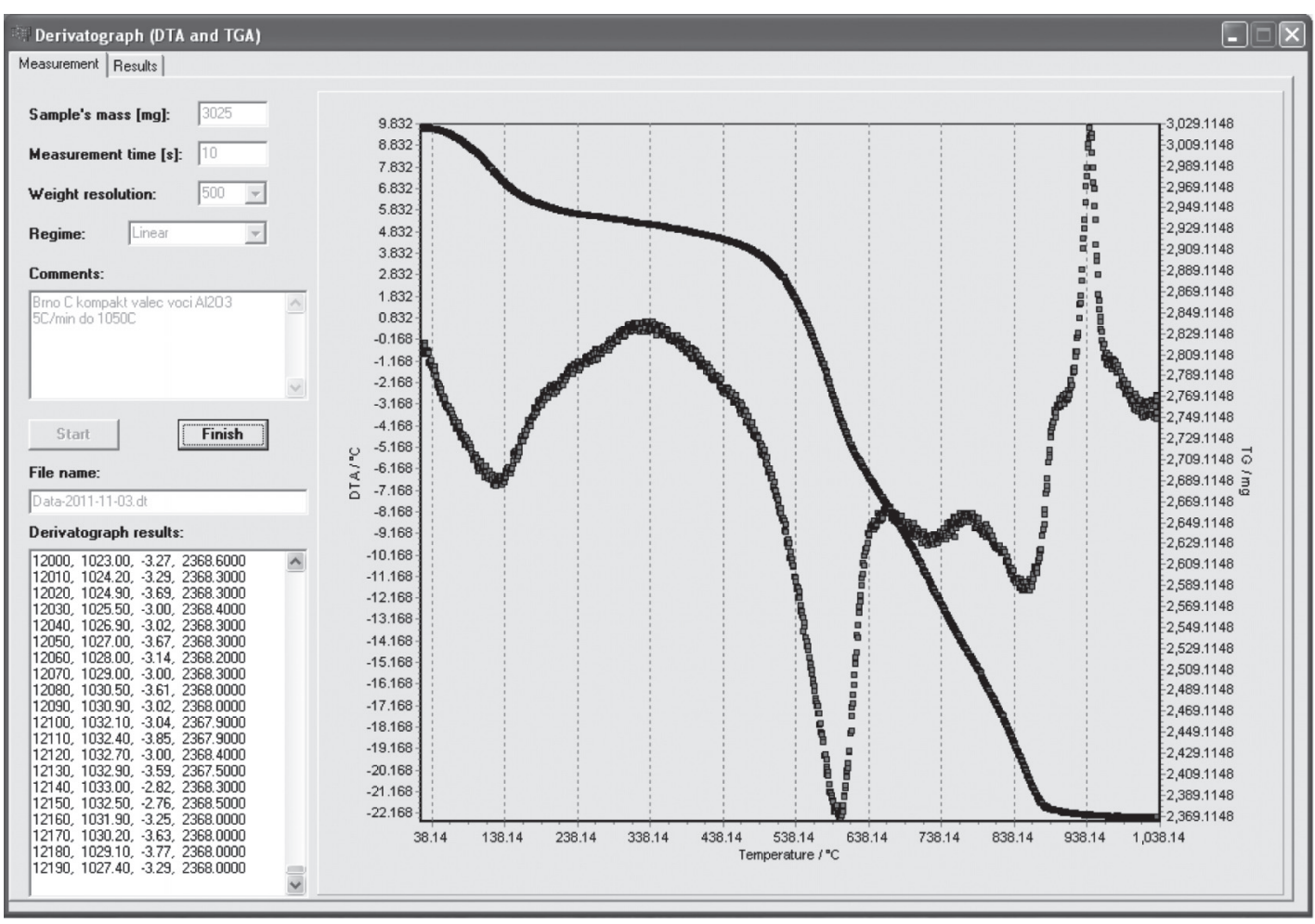

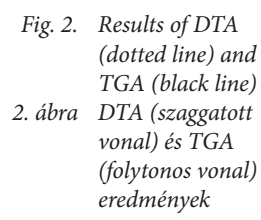

Electrical signals from the LVDT and thermocouples are lead by shielded cables to the inputs of the digital multimeter AGILENT 34972A which is connected to a PC. The program transforms the input thermoelectrical voltage $U_{t c}$ into the temperature $T$ with the help of the formula for conversion $U_{t c}$ $[\mu \mathrm{V}] \rightarrow T\left[{ }^{\circ} \mathrm{C}\right]$ given in [2]. The furnace temperature and the temperature difference for the DTA are obtained this way. The output voltage from the LVDT is converted into the change of the sample mass using a formula derived from the results of the LVDT calibration. The program records four types of data: the time of the measurement $t$, the furnace temperature $T$, the difference between the temperatures of the measured and the reference samples $\Delta T$, and the mass of the sample $m$ (see window "Derivatograph results" in Fig. 2.) which can be used for processing in a different format, e.g., in Excel (Microsoft). The TGA and DTA curves which are visible on a screen are drawn continuously.

The initial input data are the sample mass, repeating frequency of the measurement (one measurement in $10 \mathrm{~s}$ in Fig. 2.), sensitivity of the balance, and the type of the temperature regime (linear or isothermal heating).

To illustrate this, we show a screen capture (Fig. 2.) with TGA and DTA curves for the compact sample (60 wt.\% kaolinitic clay, 20 wt. $\%$ filler and 20 wt. $\% \mathrm{CaCO}_{3}$ ). Both the measured and the reference samples are approximately of the same size and mass. They have a cylindrical shape with an opening of $\varnothing 3 \times 8 \mathrm{~mm}$ in the axis of rotation used to insert them on thermocouples. The reference sample is made from pressed $\mathrm{Al}_{2} \mathrm{O}_{3}$ powder.

Some examples of the use of the modernized Derivatograph are in our previous works $[3,4,5]$.

\section{Acknowledgement}

This work was supported by the grant VEGA 1/0646/12, financed by the Ministry of Education of Slovakia. Author A.T. gratefully acknowledges a financial support from the Czech Science Foundation, Project No. P105/12/G059.

\section{References}

[1] Derivatograf system F. Paulik, J. Paulik a L. Erdey, manual, MOM Budapest

[2] ITS-90 Thermocouple Direct \& Inverse Polynomials. http://www.omega. com/pdf/temperature/Z/pdf/z198-201.pdf, online, 7.11.2011

[3] Trník, A. - Štubňa, I. - Varga, G. - Podoba, R. - Bačík, P.: Young's modulus of heatproof tile ceramics Letovice during firing. Journal of the Ceramic Society of Japan, 119, 2011, 645-649

[4] Štubňa, I. - Trník, A. - Vozár, L.: Thermomechanical and thermodilatometric analysis of green alumina porcelain. Ceramics International, 35, 2009, 1181-1185

[5] Štubňa, I. - Trník, A. - Vozár, L.: Determination of Young’s Modulus of Ceramics from Flexural Vibration at Elevated Temperatures. Acta Acustica united with Acustica, 97, 2011, 1-7

Ref.: http://dx.doi.org/10.14382/epitoanyag-jsbcm.2012.5 Rudolf Podoba - Luboš Podobník: Upgrading of TGA/DTA analyzer derivatograph. Építőanyag, 64. évf. 1-2. szám (2012), 28-29. p.

\section{Egy derivatográf (TGA/DTA elemzőberendezés) \\ korszerüsítése}

A közleményben egy Derivatograph $1100^{\circ}$ típusú TGA/DTA elemzőberendezés korszerúsítésérôl számolunk be. A minta tömeg változását a mérleg elmozdulását követố változtatható differenciális átalakítóval (LVDT) követjük. A kemence hốmérsékletét az eredeti helyzetben rögzített Pt-PtRh10 hőelemmel mérjük és az TLK 38 hőmérsékletprogramozóval szabályozzuk. A DTA hőelemeket és csatlakozóikat az eredeti helyükön rögzítettük. Az LVDT-bốl és a hôelemekbôl érkezó elektromos jeleket egy számítógéphez csatlakozó AGILENT 3497A típusú multiméterhez továbbítjuk. A program a következố jellemzôket rögzíti: mérés idôpontját, a kemence hômérsékletét, és mért és a referenciaminták közötti hốmérsékletkülönbséget és a minta tömegét. A program grafikusan szolgáltatja a TGA és DTA görbéket.

Kulcsszavak: differenciális termikus elemzés (DTA), thermogravimetriás elemzés (TGA) 